\title{
Distributed, right-lateral strike-slip in Prins Karls Forland, western Svalbard
}

\section{ALAN MORRIS}

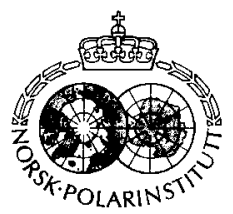

\begin{abstract}
Morris, A. 1989: Distributed, right-lateral strike-slip in Prins Karls Forland, western Svalbard. Polar Research 7, 79-82.

The 'Scotiadalen Fault' appears on many maps but has not been identified as a single fault in the field. In addition, the sense of motion on the fault has been an open question. Here I show that this structure is a zone of distributed dextral strike-slip that is probably the result of Tertiary plate motion as the North Atlantic opened. As such it is one of the very few fault zones documented to show direct evidence of dextral, presumably Tertiary, strike-slip.
\end{abstract}

Alan Morris, Division of Earth and Physical Sciences, University of Texas, San Antonio, TX 78285, U.S.A.; November 1988 (revised January 1989).

The island of Prins Karls Forland lies off the west coast of Svalbard, parallel to Caledonian orogenic trends and the Tertiary-aged Forlandsundet graben (Fig. 1). Both Caledonian (Ordovician-Silurian) and Tertiary deformation are pronounced in the region (e.g. Morris 1988; Maher et al. 1986; Craddock et al. 1985; Birkenmajer 1981; Harland \& Horsfield 1974). Mountains run almost the whole length of the island but the central portion is notable for a NS valley, Scotiadalen, which has long been thought to be occupied by a major NS fault (Atkinson 1960), the Scotiadalen Fault. No agreement exists on published maps as to the nature of the fault (e.g. Hjelle et al. 1979; Steel et al. 1984; Lepvrier et al. 1988; Nøttvedt et al. 1988), and a single fault has not been identified by detailed mapping (Harland et al. 1979). However, numerous NE trending, right-lateral faults, and tension joint orientations indicate that the area is the locus of distributed dextral shear, which probably occurred during the Tertiary (Paleocene-Eocene).

\section{Fracture analysis}

Faults

Along $15 \mathrm{~km}$ of outcrop 28, sub-vertical, NEtrending faults displace members of the Kniv- odden and Hornnes Formations (Fig. 1; stratigraphic nomenclature after Harland et al. 1979). Apparent displacement is consistently rightlateral. These faults could be either right-lateral, strike-slip faults, or, because bedding dips are predominantly to the SW throughout the area (Fig. 1) they could be normal faults with downthrow to the north. No kinematic indicators were recorded along the fault surfaces, and thus the precise nature of these faults is not known.

\section{Joints}

Fig. 1 shows the orientations of joints in the area of outcrop dominated by the NE-trending, rightlateral faults. Tension joints within the measured populations are sub-vertical, and show strong preferred orientation patterns. In the southern portion of the area sub-vertical joints cluster about a NE-SW trend. Similar joints in the northern portion of the area show a bimodal distribution with ENE-WSW and NNW-SSE populations; intervening areas show patterns transitional between these extremes.

\section{Interpretation of fracture patterns}

The faults can be interpreted in two ways: 1 ) as Riedel, $\mathbf{R}_{1}$, fractures (Riedel 1929) with pure strike-slip motion; 2) as extensional features with 


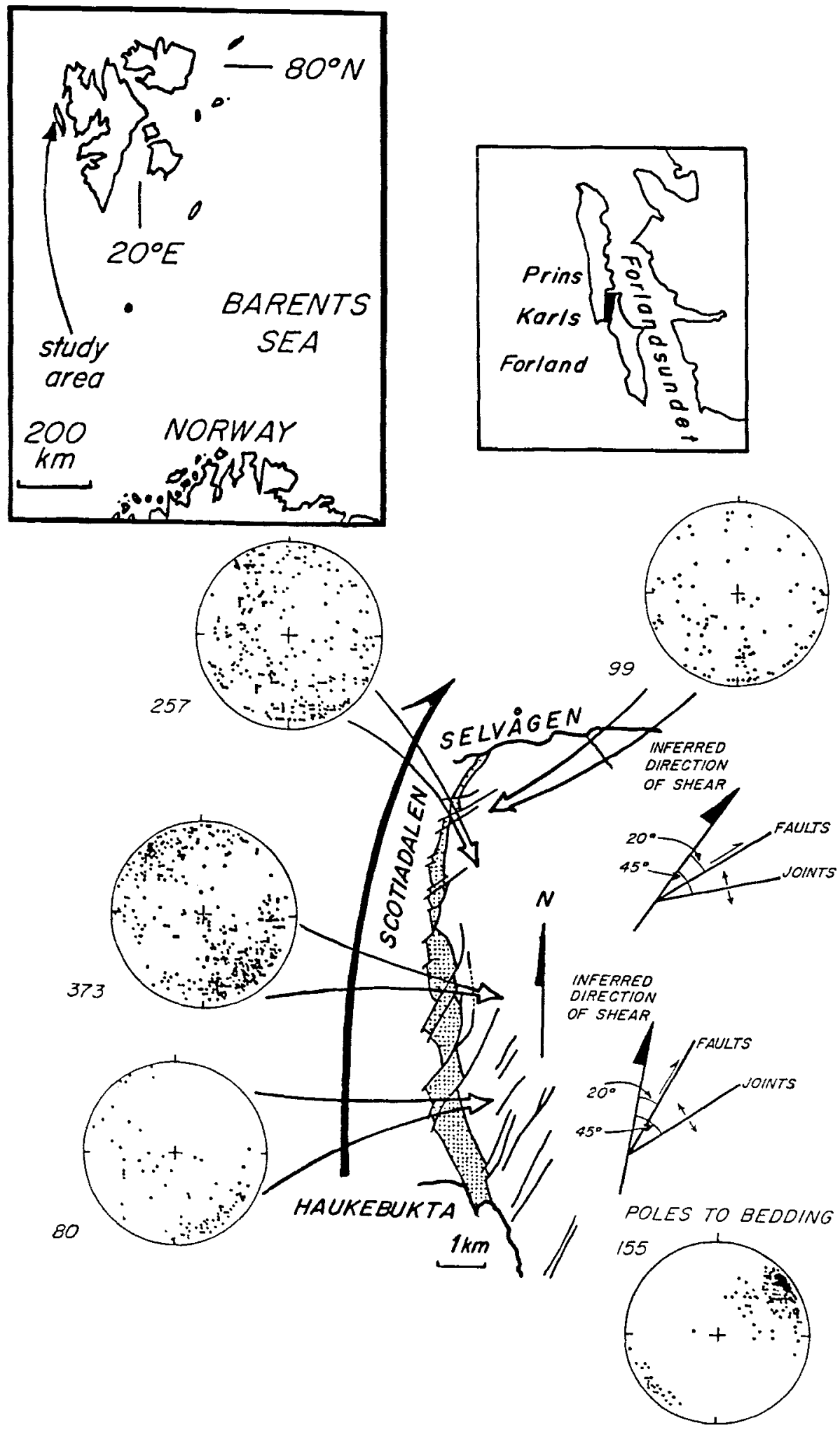


pure dip-slip motion. In either case their en echelon arrangement indicates dextral shear distributed through the study area. Assuming that the tension joints are genetically related to the faulting, and that they faithfully record the extension direction that developed as a result of shear, the Riedel fracture interpretation is preferred. Fig. 1 shows that Scotiadalen can be regarded as a curved zone of distributed dextral shear, with a total displacement of stratigraphic markers of approximately $6 \mathrm{~km}$. The angular relationships between the faults and tension joints are such that they are mutually consistent with the inferred shear directions shown in Fig. 1. The bimodal tension joint distribution towards the northern end of the area being considered can be explained as the result of superimposed joint formation associated with late Tertiary graben formation.

\section{Regional setting and timing}

Strike-slip motion has been postulated for this region during both Caledonian and Tertiary orogenic events. During the late Caledonian, Harland \& Wright (1979) suggest sinistral motion along NS trending zones $50 \mathrm{~km}$ to the east, and Ratliff et al. (1988) demonstrate dextral motion along NW-SE zones $15 \mathrm{~km}$ to the east. Tertiary age deformation is thought to have occurred as the result of dextral strike-slip along the western margin of Svalbard (Müller \& Scotese 1988; Craddock et al. 1985; Birkenmajer 1981; Talwani \& Eldholm 1977). Fig. 2 shows the relative plate motion vector of the Greenland/North American plate with respect to the Svalbard region during the Tertiary (drawn from data in Müller \& Scotese 1988). Although much of the inter-plate motion was probably accommodated along the Hornsund Fault Zone (Riis \& Vollset 1988) offshore to the west of Svalbard, plate interactions created a zone of distributed transpression followed by transtension along the western margin of the archipelago (stippled area in Fig. 2; Steel et al. 1984). There is some disagreement as to the nature of onshore Tertiary faulting in western Svalbard. Ohta (1988) invokes sinistral strike-slip in western Oscar II Land, while Lepvrier et al. (1988) inter-

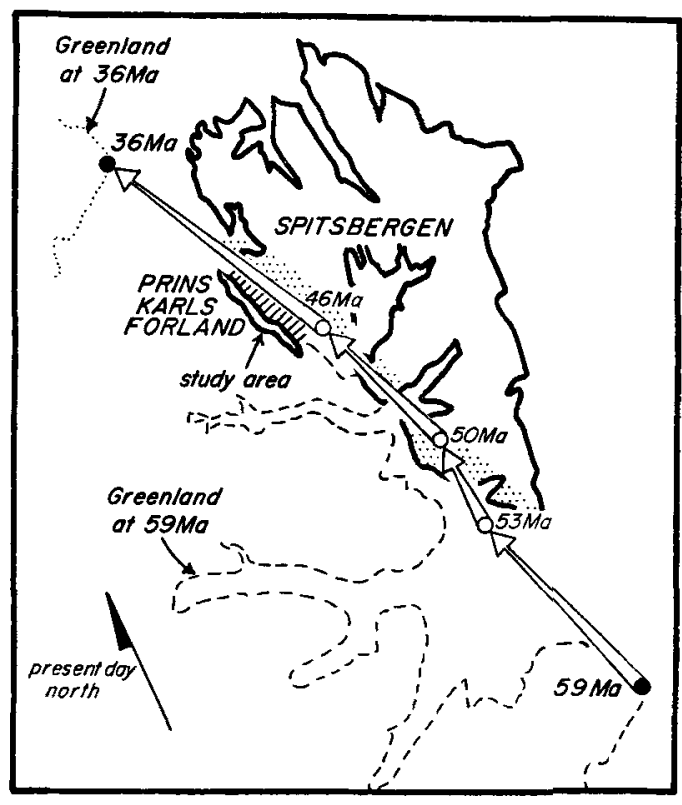

Fig. 2. Map of the island of Spitsbergen (the largest member of the Svalbard archipelago) showing the Tertiary fold-thrust belt (stippled), Forlandsundet Tertiary graben (hatched), and the study area on Prins Karls Forland. Superimposed on this is the relative motion vector of part of the present-day coastline of Greenland from $59 \mathrm{Ma}$ to $36 \mathrm{Ma}$. Data from Müller \& Scotese (1988) and Steel et al. (1984).

pret the same area as an early Tertiary dextral fault. Many faults are mapped but few have documented kinematic indicators.

The relatively simple geometrical relationships and the lack of secondary modification of the Scotiadalen fault zone argue against a Paleozoic origin. The distributed shear zone described here is well orientated to accommodate shear strain developed during the Tertiary, and probably formed prior to the transtensional phase of this deformation (late Eocene to mid-Oligocene, say 40-30 Ma; Steel et al. 1984; Lepvrier et al. 1988).

Acknowledgements. - Funding for the field work described here was provided by the Natural Environment Research Council of the United Kingdom and logistical support was given by Brian Harland and the Cambridge Spitsbergen Expeditions. I am indebted to Geoff Manby for many discussions in the field, and to Shankar Mitra whose telephone conversation prompted the re-examination of old ficld maps. I thank Yoshihide Ohta for critical review of the first draft of this paper.

Fig. 1. Map showing the location of the study area. The stippled pattern represents the Knivodden Formation (Harland et al. 1979). Also shown are lower hemisphere, equal area projections of measured joints and bedding surfaces in central Prins Karls Forland. The numbers give the number of data points in that set, and the point plots are poles to plane (joint or bed) surfaces. Inferred shear directions in different parts of the study area are based upon an interpretation of the faults as Riedel, $\mathbf{R}_{1}$, shear fractures, and the tension joints as a direct result of the associated stress régime. 


\section{References}

Atkinson, D. J. 1960: Caledonian tectonics of Prins Karls Forland. International Geological Congress, 21st Session 19, 1727.

Birkenmajer, K. 1981: The geology of Svalbard, the western part of the Barents Sea, and the continental margin of Scandinavia. Pp. 265-329 in Nairn, A. E. M., Churkin, M. \& Stehli. F. G. (eds.): The Ocean Basins and Margins 5. The Arctic. Plenum Press. New York.

Craddock, C., Hauser, E. C., Maher, H. D. Sun, A. Y. \& Zhu, G.-Q. 1985: Tectonic evolution of the west Spitsbergen fold belt. Tectonophysics 114, 193-211.

Harland, W. B. \& Horsfield, W. T. 1974: West Spitsbergen orogeny. Pp. 747-755 in Spencer, A. M. (ed.): MesozoicCenozoic orogenic bells, data for orogenic studies. Geological Society (London) Special Publication 4.

Harland, W. B., Horsfield, W. T., Manby, G. M. \& Morris, A. P. 1979: An outline pre-Carboniferous stratigraphy of central western Spitsbergen. Norsk Polarinstitutt Skrifter 167, 119-144

Harland, W. B. \& Wright, N. J. R. 1979: Alternative hypothesis for the pre-Carboniferous cvolution of Svalbard. Norsk Polarinstitutt Skrifter 167,89-117.

Hjelle. A. Ohta, Y.\& Winsnes, T. S. 1979: Hecla Hoek rocks of Oscar II Land and Prins Karls Forland. Svalbard. Norsk Polarinstitutt Skrifter 167, 145-169.

Lepvrier, C. Leparmenticr, F. \& Seland, R. 1988: Tertiary stress evolution on Svalbard. Norsk Polarinstitutt Rapport 46. $59-61$.

Maher, H. D., Craddock, C. \& Maher, K. 1986: Kinematics of Tertiary Structures in the upper Paleozoic and Mesozoic strata on Midterhuken, west Spitsbergen. Geological Society of America Bulletin 97, 1411-1421.

Morris. A. P. 1988: Polyphase deformation in Oscar II Land, central western Svalbard. Polar Research 6, 69-84.

Muller, R. D. \& Scotese, C. R. 1988: The tectonic development of the North Atlantic: Revised seafloor spreading isochrons and tectonic fabric map from Seasat altimetry. Paleoceanographic Mapping Project Progress Report 26-1287.

Nøttvedt, A., Livbjerg, F. \& Midbøe, P. S. 1988: Tertiary deformation of Svalbard - various models and recent advances. Norsk Polarinstitutt Rapport 46, 79-84.

Ohta, Y. 1988: Structures of Carboniferous strata at Trygghamna and along the SE margin of the Forlandsundet graben. Norsk Polarinstitutt Rapport 46, 25-28.

Ratliff, R., Morris, A. \& Dodt, M. 1988: Interaction between strike-slip and thrust-shear: deformation of the Bullbreen Group, central-western Spitsbergen. Journal of Geology 96 , 339-349.

Riedel, W. 1929: Zur Mechanik geologischer Brucherscheinungen. Zent. Min. Geol. Pal., 354-368.

Riis. F. \& Vollset, J. 1988: A preliminary interpretation of the Hornsund Fault Complex between Sørkapp and Bjørnøya. Norsk Polarinstitutt Rapport 46, 91-92.

Steel. R., Gjelberg, J., Helland-Hansen, W., Kleinspehn, K. Nøttvedt, A. \& Rye-Larsen, M. 1984: The Tertiary strikeslip basins and orogenic belt of Spitsbergen. Pp. 339-359 in Spencer. A. M. (ed.): Petroleum geology of the northern European Margin. Norwegian Petroleum Industry (Graham \& Trotman, London).

Talwani, M. \& Eldholm, O. 1977: Evolution of the NorwegianGreenland Sea. Geological Society of America Bulletin 88, 969-999. 

